\title{
Selection in the genetic resource: genetic variation of the linear described type traits in the Old Kladrub horse
}

\author{
VÁCLAV JAKUBEC ${ }^{1}$, LUBOŠ VOSTRÝ ${ }^{1}$, WERNER SCHLOTE², IVAN MAJZLÍK ${ }^{1}$ and KAREL \\ $\mathrm{MACH}^{1}$
}

'Faculty of Agrobiology, Nature and Food Resources, Czech University of Life Sciences Prague, Prague, Czech Republic, ${ }^{2}$ Berlin, Germany

\section{Abstract}

The structure of the breed in 2003 was: 39 sires and 350 dams. The breed was closed against immigration in 1992. In 1993 and 2003 coefficients of inbreeding $\left(F_{x}\right)$ were calculated from 5 parental generations for sires and dams in the whole breed and white and black variety. From 1993 to 2003 decreased the $F_{x}(\%)$ in the breed for stallions from 5.65 to 5.57 and for mares from 7.75 to 4.88 . The effective population size was in 1993 $N_{e}=114.00$ and $2003 N_{e}=140.36$. The increment of $N_{e}$ during the 10-year period was 26.36 animals. The average heterozygosity estimated on the frequencies of blood types, biochemical markers and microsatellites was enough large and was connected with a low coefficient of inbreeding. Linear type evolutions of 494 horses of the Old Kladrub breed for 32 traits were used to analyse the effect of variety and stud. The data were used for the estimation of population parameters and heritability coefficients. The specific properties and variation of the Old Kladrub horse in its current state were characterized by the overall mean, standard deviation, coefficient of variation, number of utilized scores and heritabilities. The highest coefficient of variation showed the forelimbs-side view (40.14\%), chest girth (36.25\%) and height at withers (30.97\%). The 8 traits showed heritabilities within the interval of 0.20 to 0.68 . These traits are candidates as selection criteria. Significant differences between both varieties were found in 13 from 32 traits. Significant differences were found in 12 of 32 traits between the Kladruby stud and the private studs.

Keywords: horse, Old Kladrub, rate of inbreeding, polymorphism, linear type traits, varieties, population parameters

\section{Zusammenfassung}

\section{Selektion in der genetischen Resource: Genetische Variation der linearen Merkmale in der Altkladruber Pferderasse}

Die Rassestruktur war im Jahr 2003: 39 Zuchthengste und 350 Zuchtstuten. Gegen Immigration wurde die Rasse im Jahre 1992 geschlossen. Der Inzuchtkeoffizient $\left(F_{x}\right)$ wurde im Jahre 1992 und 1993 von 5 Elterngenerationen getrennt für die Hengste und Stuten in der Gesamtpopulation und in der Grauschimmel- und Rappenvarietät berechnet. Der Inzuchtkoeffizient $\left(F_{x,} \%\right)$ sank von 1993 bis 2003 für die Hengste von 5,65 auf 5,57 und für die Stuten von 7,74 auf 4,88. Die effektive Populationsgrösse $\left(N_{e}\right)$ war im Jahre $1993 N_{e}=114.00$ und 2003 $N_{e}=140.36$. Der Zuwachs von $N_{e}$ betrug während des Zeitabschnittes von 10 Jahren 26,36 Tiere. 
Der Heterozygotiegrad gemessen mit Hilfe von Blutgruppen, biochemischen Markern und Mikrosatelliten war genügend groß und stand im Zusammenhang mit einem niedrigen Inzuchtkoeffizienten. Lineare Exterieurbeurteilungen von 494 Pferden der Altkladruber Rasse für 32 Merkmale wurden herangezogen, um den Einfluss der Varietät (Grauschimmel und Rappen) und des Gestütes zu untersuchen. Die lineare Exterieurbeurteilung wurde von einer einzigen Person durchgeführt. Die Daten wurden zur Schätzung von Populationsparametern und Heritabilitätskoeffizienten herangezogen. Merkmale und die Variation der Altklaruber Rasse wurde mit Hilfe dieser Parameter geschätzt: allgemeiner Mittelwert, Standardabweichung, Variationskoeffizient, genutzte Punktanzahl und Heritabilität. Der höchste Variationskoeffizient wurde bei den Merkmalen Seitenansicht der Vorderbeine $(40,14 \%)$, Brustumfang (36,25\%) und Widerristhöhe (30.97\%) festgestellt. Für 8 Merkmale wurde die Heritabilität im Intervall von 0,20 bis 0,68 geschätzt. Diese Merkmale kommen als Selektionskriterienkandidaten in betracht. Signifikante Unterschiede zwischen den Varietäten wurden für 13 von 32 Merkmalen gefunden. Bei 12 der 32 Merkmale wurden signifikante Unterschiede zwischen dem Kladruber Gestüt und den privaten Züchtern festgestellt.

Schlüsselwörter: Pferd, Kladruber, Inzuchtkoeffizienten, Polymorphismus, lineare Exterieurmerkmale, Varietäten, Populationsparameter

\section{Introduction}

The Old Kladrub horse is the most important Czech genetic resource and was established by the end of the 18th and at the beginning of the 19th century. The breed existing today is a warmblood created on the basis of Old Spanish and Old Italian horses and was bred continuously in the Czech Republic for more than two hundred years. The breed is a robust carriage (coach) horse, which was originally used for ceremonial purposes by the Habsburg emperors and the clerical hierarchy. The population was closed against gene immigration from related breeds of Old Spanish origin in 1992. Due to imperial tradition, the breed consists of a grey and a black variety. The breeding population is located in the stud Kladruby (grey variety) and Slatiňany (black variety) of the National Stud Kladruby nad Labem and in private studs in the middle of Bohemia and southern parts of Moravia.

From the very beginning it has been a population of limited number and because of this inbreeding took place over centuries and especially in the past decades. Inbreeding in its consequences could lead to inbreeding depression and to decrease of genetic variation. This is why it is necessary, in the framework of repeated genetic analyse, to pay attention to the rate of inbreeding. VOLENEC et al. (1995) carried out a preliminary study of inbreeding of the Old Kladrub horse.

The extraordinary type and the specific external traits of this breed should be safed for the next generations. It is evident that for such a specific coach horse, the breeding objective must be focused on the conformation traits. In 1995, a new linear type trait classification system was developed for the Old Kladrub horse (JAKUBEC et al. 1996a). The integral parts of this system are the description of colour and marks and body conformation failures. The new system was verified in 1995 in the grey and black variety of the National Stud of Kladruby nad Labem. The analysis included also further factors as: sex, age at classification and sire lines. The results of the analysis were published by 
JAKUBEC et al. (1998, 1999, 2000) and SCHLOTE et al. (2002). Since 1996 the linear type classification was extended to private farmers. The linear type trait classification is an inevitable tool of the breeding program of the Old Kladrub horse for retaining specific conformation traits for next generations. Besides the performance recording, the linear classification will be an effective tool for the precise determination of the breeding objective. This linear type trait classification system contributes to the increasing of the phenotype and genetic variability of the animals within the breed and breeding groups (sire lines and dam families).

Several authors (VAN BERGEN and VAN ARENDONK 1993, HARTMANN et al. 1994, KOENEN et al. 1994) estimated genetic parameters for breeds of riding horses and Shetland ponies. In addition to these genetic parameter estimates of heritabilities for linear type traits of the Bardigliano horse were estimated by FIORETTI et al. (2005). This breed is an ancient Italian genetic resource. EKiZ et al. (2005) estimated phenotypic and genetic parameter for racing traits of Thoroughbred horse in Turkey. DIESTL et al. (2004) and POSTA et al. (2007) tested genetic evaluation procedures for German and Hungarian Sporthorse mares and HALO et al. (2008) evaluated efficiency test result of Slovak warmblood horses. STÜBS and DIESTL (2007) describe the current situation of horse genome mapping and its impact on equine genomics for identification of genes for different traits.

The objective of the paper is the development and rate of inbreeding of the Old Kladrub breed within the period form 1993 to 2003, the analysis of linear type traits with regard to the variety (grey and black), National Stud of Kladruby nad Labem and studs of private farmers from 1995 to 2005 and the estimation of heritability coefficients of the linear type traits.

\section{Material and methods}

The structure of the breeding animals of the colour varieties in the year 2003 was analysed. Coefficients of inbreeding were calculated for all horses (stallions and mares) from the information of 5 generations of ancestors according to WRIGHT (1922). The genetic analysis was carried out in the year 2003 in the same way as in the year 1993. The individual coefficients of inbreeding were used for the calculation of average coefficients of inbreeding for the whole population and varieties. The actual results of the analysis (2003) were compared with those obtained in 1993 and the shift in the rate of inbreeding within this 10-year breeding period was analysed.

The coefficients of inbreeding were used as a measure of the dispersive process. The effective population size $\left(N_{e}\right)$, variance of the change of gene frequency $\left(\sigma_{\Delta q}^{2}\right)$ and expected increment of inbreeding $(\Delta F)$ in one generation were calculated according to FALCONER and MACKAY (1996). The counterparts of the mathematical tools for describing the genetic diversity are genetic methods which analyse the frequencies of alleles. Differences in these frequencies were shown by different types of markers: blood types. Biochemical markers microsatellites, which were published by JAKUBEC et al. (1996b) and HOŘín et al. (1998), are shown in Table 4.

A qualified classifier described 494 horses from 1995 to 2004. The classifier used a scale of 1 to 9 points for 32 linear type traits with increments of one point, where the parameters represented the extremes in the biological variation: 
- front: height at withers, head profile, neck length, neck tethering, neck topside, withers length, withers height

- body: topline length, topline vault, loin length, loin vault, shoulder length, shoulder slope, chest girth, chest length, chest width, chest depth, breast width

- rear: croup length, croup width, croup shape, croup profile, tail tethering

- limbs: forelimbs-front view, forelimbs-side view, canon bone circumference, foretoes-side view, forehoof side view, forehoof width, forehoof size, hind limbsside view, hind limbs-back view.

The frequency of animals within the factors and effects is shown in Table 1.

The population parameters of the linear type traits were analysed by the least-squares analysis using the GLM procedure (SAS 2005). The following linear model was used:

$$
Y_{i j k l m n}=\mu+V A R_{i}+S T U D_{j}+S E X_{k}+Y E A R B_{1}+A G E C_{m}+(V A R \cdot S T U D)_{i j}+e_{i j k m n}
$$

where is $Y_{i j k m n}$ the observation of a linear type trait, $\mu$ the overall mean, VAR $R_{i}$ the fixed effect of the $i$-th variety, $S T U D_{j}$ the fixed effect of the $j$-th stud, $S E X_{k}$ the fixed effect of the $k$-th sex, YEARB, the fixed effect of the $l$-th year of birth, $A G E C_{m}$ the fixed effect of the $m$-th age at classification, (VAR.STUD $)_{i j}$ the fixed effect of the $i j$-th interaction variety $\times$ stud and $e_{i j k l m n}$ the random residual error.

The F-test statistic was used to determine the significance of the effects $\left({ }^{*} P<0.05\right.$, $\left.{ }^{*} P<0.01,{ }^{* * *} P<0.001\right)$.

The heritabilities were estimated by an animal model using the program VCE5 (KOVAČ et al. 2002). In addition the random effect of the $o$-th animal $\left(A N I M A L_{n}\right)$ was included in the above mentioned model:

$$
\begin{aligned}
Y_{i j k l m n o}= & \mu+V A R_{i}+S T U D_{j}+S E X_{k}+Y E A R B_{l}+A G E C_{m}+A N I M A L_{n} \\
& +(V A R \cdot S T U D)_{i j}+e_{i j k l m n o}
\end{aligned}
$$

\section{Results and discussion}

\section{Development of the breed}

The structure of the breeding animals of the Old Kladrub horse in the year 2003 is shown in Table 1 and 2. The breeding population consisted of 389 breeding horses (39 sires and 350 dams). Within the 10-year breeding period (1993-2003) the number of sires increased from 33 to 39 (Table 2). This increment was only slight, and it was due the increase of sires in the grey variety (from 16 to 22). The number of sires in the black variety was the same (17) in both years 1993 and 2003. During the same period the number of mares increased from 209 (95 grey and 114 black) to 350 (169 grey and 181 black) - Table 3.

\section{Rate of inbreeding}

\section{Stallions}

The Table 1 shows also average inbreeding coefficients of stallions within both varieties in 1993 and 2003. The average coefficient of inbreeding for the whole population and in both varieties of the stallions remained within the 10 years period almost unchanged. In the 
grey variety decreased the $F_{x}$ from $6.06 \%$ to $5.20 \%(-0.86 \%)$. The average coefficient of inbreeding increased in the black variety from $5.26 \%$ to $5.94 \%$ (0.68\%). In the whole breed no success in the diminishing of the average coefficient of inbreeding for stallions within the population from 1993 to 2003 has been recorded. Despite the matings between as far as possible unrelated stallions and mares and realized circular group mating the average coefficient of inbreeding of the breed left unchanged during the period of ten years. This can be explained by the fact, that when stallions were selected for breeding emphasis was first of all put on the results of the performance test and conformation evaluation.

Table 1

Frequency of animals within the factors and effects

Tierhäufigkeit innerhalb von Faktoren und Effekten

\begin{tabular}{|c|c|c|c|}
\hline Factor & Effect & Frequency & Percent \\
\hline \multirow[t]{2}{*}{ Variety } & Grey & 255 & 51.62 \\
\hline & Black & 239 & 48.38 \\
\hline \multirow[t]{2}{*}{ Stud } & Kladruby n. L. & 201 & 40.69 \\
\hline & Private farmers & 293 & 59.31 \\
\hline \multirow[t]{2}{*}{ Sex } & Stallions & 63 & 12.75 \\
\hline & Mares & 431 & 87.25 \\
\hline \multirow[t]{16}{*}{ Year of birth } & 1985 & 11 & 2.23 \\
\hline & 1986 & 15 & 3.04 \\
\hline & 1987 & 21 & 4.25 \\
\hline & 1988 & 30 & 6.07 \\
\hline & 1989 & 28 & 5.67 \\
\hline & 1990 & 40 & 8.10 \\
\hline & 1991 & 30 & 6.07 \\
\hline & 1992 & 31 & 6.28 \\
\hline & 1993 & 42 & 8.50 \\
\hline & 1994 & 45 & 9.11 \\
\hline & 1995 & 45 & 9.11 \\
\hline & 1996 & 37 & 7.49 \\
\hline & 1997 & 31 & 6.28 \\
\hline & 1998 & 33 & 6.68 \\
\hline & 1999 & 42 & 8.50 \\
\hline & 2000 & 13 & 2.63 \\
\hline \multirow[t]{8}{*}{ Age at classification } & 3 & 45 & 9.11 \\
\hline & 4 & 212 & 42.91 \\
\hline & 5 & 78 & 15.79 \\
\hline & 6 & 43 & 8.70 \\
\hline & 7 & 48 & 9.72 \\
\hline & 8 & 25 & 5.06 \\
\hline & 9 & 22 & 4.45 \\
\hline & 10 & 21 & 4.25 \\
\hline
\end{tabular}




\section{Mares}

The Table 2 shows average inbreeding coefficients of mares within both varieties in 1993 and 2003. The average coefficient of inbreeding for the whole population (grey and black lines) of mares decreased from the value $7.75 \%$ to $4.88 \%(-2.87 \%)$ within the 10 year period. The $F_{x}$ decreased in the grey variety from $7.29 \%$ to $3.99 \%(-3.30 \%)$ and in the black one from $8.40 \%$ to $5.86 \%(-2.54 \%)$. In the whole dam population the reduction of the average coefficient of inbreeding between 1993 and 2003 was remarkable. Within the period of ten years the number of mares increased from 209 to 350, i.e. an increase of 141 mares $(67.5 \%)$. Obviously two main reasons were responsible for this decrease of the coefficient of inbreeding. The first one was the rapid breed growth which resulted also in an increase of the effective size. The second one was the application of circular group mating.

Table 2

Average inbreeding coefficients of stallions within both varieties in 1993 and 2003

Durchschnittliche Inzuchtkoeffizienten für Hengste beider Varietäten in 1993 und 2003

\begin{tabular}{lccccccc}
\hline Year & \multicolumn{2}{c}{1993} & \multicolumn{2}{c}{2003} & Difference $F_{\bar{x},} \%$ & Minimal $F_{\bar{x},} \%$ & Maximal $F_{\bar{x},} \%$ \\
Variety & $n$ & $F_{\bar{x},} \%$ & $n$ & $F_{\bar{x},} \%$ & & 0.00 & 9.57 \\
\hline Grey & 16 & 6.06 & 22 & 5.20 & -0.86 & 0.00 & 11.72 \\
Black & 17 & 5.26 & 17 & 5.94 & 0.68 & 0.00 & 11.72 \\
\hline Total & 33 & 5.66 & 39 & 5.57 & -0.09 & \\
\hline
\end{tabular}

$F_{\bar{x}}$ refer to values in 2003

Table 3

Average inbreeding coefficients of mares within both varieties in 1993 and 2003

Durchschnittliche Inzuchtkoeffizienten für Stuten beider Varietäten in 1993 und 2003

\begin{tabular}{|c|c|c|c|c|c|c|c|c|c|}
\hline \multirow{2}{*}{ Variety } & & 1993 & & & 2003 & & \multirow{2}{*}{ Difference $F_{\bar{x}}, \%$} & \multirow{2}{*}{ Minimal $F_{\bar{x}} \%$} & \multirow{2}{*}{ Maximal $F_{\bar{x},} \%$} \\
\hline & Sires, $I$ & Dams, $n$ & $F_{\bar{x},} \%$ & Sires, & Dams, $n$ & $F_{\bar{x},} \%$ & & & \\
\hline Grey & 16 & 95 & 7.29 & 14 & 169 & 3.99 & -3.30 & 0.00 & 13.48 \\
\hline Black & 17 & 114 & 8.40 & 8 & 181 & 5.86 & -2.54 & 1.37 & 17.97 \\
\hline Total & 33 & 209 & 7.75 & 22 & 350 & 4.88 & -2.87 & 0.00 & 17.97 \\
\hline
\end{tabular}

\section{Effective population size $\left(N_{e}\right)$}

The interval of ten years corresponds approximately to the generation interval of 10 years in the Old Kladrub horse. In the Old Kladrub breed were in 199333 stallions and 209 mares and in 200339 stallions and 350 mares. We have found $N_{e}=114.00$ in the year 1993 and $N_{e}=140.36$ in the year 2003. The increment of $N_{e}$ during the 10 -year period was 26.36 animals.

The rate of inbreeding in a random mated population is:

$$
\Delta F=\frac{1}{8 N_{m}}+\frac{1}{8 N_{f}}
$$

If random mating was applied the rate of inbreeding with respect to the number of sires and dams was $0.4386 \%$ in 1993 and $0.3562 \%$ in 2003 . The change of inbreeding would be very low. 


\section{Polymorphism of blood types, biochemical markers and microsatellites}

The average heterozygosity and coefficient of inbreeding for both varieties are shown in Table 4. The average heterozygosity of the Old Kladrub breed was lower than the same parameter estimated by another authors using blood type and biochemical polymorphic systems: BOWLING (1994) 38.9-40.2\% and OOM and COTHRAN (1994) $37.5 \%$.

Table 4

Average heterozygosity $(h)$ and coefficient of inbreeding $\left(F_{\bar{x}}\right)$ for both varieties Heterozygotiegrad und Inzuchtkoeffizient für beide Varietäten

\begin{tabular}{lccc}
\hline Variety & $n$ & $h$ & $F_{\bar{x}}$ \\
\hline Grey & 73 & 31.2 & 6.3 \\
Black & 109 & 36.0 & 7.0 \\
Total & 182 & 34.1 & 6.7 \\
\hline
\end{tabular}

The average heterozygosity estimated by JAKUBEC et al. (1996) and HOŘín et al. (1998) for blood type and biochemical polymorphic systems as well as microsatellite markers is specified in table 5. HOŘín et al. (1998) found higher values of the average heterozygosity (0.44) at blood type and biochemical loci than JAKUBEC et al. (1996) (0.34). The average heterozygosity of microsatellites $(0.65)$ was much higher than in the blood type and biochemical loci (0.34 resp. 0.44). The average heterozygosity in the breed was enough large and was connected with a low coefficient of inbreeding.

Table 5

Average heterozygosity at blood type, biochemical and microsatellite loci in the Old Kladrub breed (HOŘín et al. 1998)

Heterozygotiegrad der Blutgruppen, biochemischer Polymorphismen und Mikrosatelliten-Loci beim Altkladruber Pferd

\begin{tabular}{lcccccc}
\hline Variety & $n$ & Blood type & Biochemical & Total & Total (JAKUBEC et al. 1996) & Microsatellite \\
\hline Grey & 63 & 0.47 & 0.34 & 0.41 & 0.31 & 0.67 \\
Black & 73 & 0.53 & 0.42 & 0.48 & 0.36 & 0.64 \\
Total & 136 & 0.50 & 0.38 & 0.44 & 0.34 & 0.65 \\
\hline
\end{tabular}

\section{Analysis and estimation of heritabilities of linear type traits}

The scale of the linear type scores describes the whole range of the possible phenotypic expressions of the trait considered across the population. Therefore, the estimates of the parameters (overall mean, standard deviation, coefficient of variation, minimum and maximum of scores, number of utilized scores) characterize the specific properties and variation of the Old Kladrub breed in its current state (Table 6).

The means and standard deviations have only an informative value. The means lie between 3.85 and 6.40 scores. The standard deviations are within the span from 0.66 to 2.32 scores. The means are not a measure of the quality of traits and the standard deviations, as a measure of variation, depend on the mean. Therefore they both will be not discussed in detail. The coefficients of variation are a more important measure of variation. It is a general assumption that a higher phenotypic variation of traits indicates a higher genetic variation which guarantees a sufficient selection response. 
Table 6

Estimates of the basic population parameters and heritability coefficients

Schätzung von Populationsparametern und Heritabilitätskoeffizienten

\begin{tabular}{|c|c|c|c|c|c|c|c|c|c|}
\hline No. & Trait & Mean & SD & $C V, \%$ & MinSc & MaxSc & USC & $h^{2}$ & SE \\
\hline & Front & & & & & & & & \\
\hline 1 & Height at withers & 5.98 & 1.85 & 30.97 & 1 & 9 & 9 & 0.438 & 0.059 \\
\hline 2 & Head profile & 5.44 & 1.44 & 26.51 & 3 & 9 & 7 & 0.675 & 0.065 \\
\hline 3 & Neck-length & 5.16 & 1.16 & 22.46 & 2 & 7 & 6 & 0.115 & 0.046 \\
\hline 4 & Neck tethering & 5.99 & 0.97 & 16.26 & 3 & 9 & 7 & 0.143 & 0.056 \\
\hline 5 & Neck topside & 6.04 & 1.68 & 27.83 & 1 & 9 & 9 & 0.152 & 0.055 \\
\hline 6 & Withers length & 4.99 & 1.48 & 29.69 & 1 & 9 & 9 & 0.073 & 0.053 \\
\hline \multirow[t]{2}{*}{7} & Withers height & 4.41 & 1.20 & 27.29 & 1 & 9 & 9 & 0.171 & 0.060 \\
\hline & Body & & & & & & & & \\
\hline 8 & Topline length & 5.57 & 1.28 & 23.02 & 3 & 9 & 7 & 0.121 & 0.066 \\
\hline 9 & Topline vault & 4.60 & 0.78 & 16.96 & 1 & 7 & 7 & 0.142 & 0.057 \\
\hline 10 & Loin length & 5.98 & 1.14 & 19.06 & 3 & 9 & 7 & 0.003 & 0.005 \\
\hline 11 & Loin vault & 4.43 & 1.05 & 23.71 & 1 & 9 & 9 & 0.054 & 0.048 \\
\hline 12 & Shoulder length & 4.52 & 0.78 & 17.25 & 3 & 7 & 5 & 0.050 & 0.052 \\
\hline 13 & Shoulder slope & 3.85 & 1.04 & 26.97 & 1 & 7 & 7 & 0.008 & 0.015 \\
\hline 14 & Chest girth & 6.40 & 2.32 & 36.25 & 1 & 9 & 9 & 0.325 & 0.055 \\
\hline 15 & Chest length & 6.14 & 1.04 & 16.88 & 3 & 9 & 7 & 0.040 & 0.058 \\
\hline 16 & Chest width & 5.15 & 1.24 & 24.10 & 3 & 9 & 7 & 0.129 & 0.057 \\
\hline 17 & Chest depth & 6.03 & 1.19 & 19.72 & 3 & 9 & 7 & 0.434 & 0.073 \\
\hline \multirow[t]{2}{*}{18} & Breast width & 5.14 & 1.29 & 25.10 & 2 & 9 & 8 & 0.135 & 0.055 \\
\hline & Rear & & & & & & & & \\
\hline 19 & Croup length & 4.15 & 0.93 & 22.33 & 1 & 7 & 7 & 0.058 & 0.046 \\
\hline 20 & Croup width & 5.89 & 1.16 & 19.63 & 3 & 9 & 7 & 0.223 & 0.068 \\
\hline 21 & Croup shape & 4.47 & 1.06 & 23.60 & 1 & 7 & 7 & 0.263 & 0.064 \\
\hline 22 & Croup profile & 4.70 & 1.35 & 28.64 & 1 & 9 & 9 & 0.148 & 0.055 \\
\hline \multirow[t]{2}{*}{23} & Tail tethering & 5.05 & 1.10 & 21.89 & 1 & 9 & 9 & 0.039 & 0.047 \\
\hline & Limbs & & & & & & & & \\
\hline 24 & Forelimbs-front view & 5.06 & 0.81 & 16.01 & 3 & 9 & 7 & 0.007 & 0.010 \\
\hline 25 & Forelimbs-side view & 4.03 & 1.62 & 40.14 & 1 & 7 & 7 & 0.069 & 0.052 \\
\hline 26 & Cannon bone circumference & 6.18 & 1.49 & 24.17 & 1 & 9 & 9 & 0.282 & 0.064 \\
\hline 27 & Foretoes side view & 4.56 & 0.90 & 19.66 & 1 & 7 & 7 & 0.096 & 0.070 \\
\hline 28 & Forehoof-side view & 4.89 & 0.95 & 19.46 & 1 & 9 & 9 & 0.111 & 0.050 \\
\hline 29 & Forehoof width & 5.05 & 1.02 & 20.21 & 3 & 7 & 5 & 0.467 & 0.065 \\
\hline 30 & Forehoof size & 4.98 & 0.66 & 13.25 & 3 & 7 & 5 & 0.162 & 0.055 \\
\hline 31 & Hind limbs-side view & 4.40 & 0.91 & 20.67 & 1 & 7 & 7 & 0.006 & 0.023 \\
\hline 32 & Hind limbs-back view & 4.94 & 0.78 & 15.80 & 3 & 9 & 7 & 0.046 & 0.055 \\
\hline
\end{tabular}

SD standard deviation, CV coefficient of variation, MinSc minimum of scores, MaxSc maximum of scores USc utilized scores, $h^{2}$ estimated heritability, SE standard error 
The traits can be dividend into 4 groups according to the magnitude of their coefficients of variation:

1. $13.25-19.99 \%$ (12 traits)

2. $20.00-24.99 \%$ (10 traits)

3. $25.00-29.99 \%$ (7 traits)

4. 30.00 and higher ( 3 traits).

The highest coefficient of variation showed the forelimbs-side view (40.14\%), chest girth $(36.25 \%)$ and height at withers (30.97\%). The last both traits were measured and the measures were transformed to scores. A relatively high coefficient of variation had the traits with values between 25-29.99\% (withers length, croup profile, neck topside, withers height, shoulder slope, head profile and breast width).

Within the span from 7 to 9 utilized scores where 28 traits from 32. Within the minimum of 1-3 scores and maximum of 7-9 scores were all traits. The classifier used a very high number of scores of the scale.

The traits were separated into 5 groups according to the magnitude of their heritabilities:

1. $\geq 0.600$ (1 trait)

2. $0.300-0.599$ (4 traits)

3. $0.200-0.299$ (3 traits)

4. $0.100-0.199$ (11 traits)

5. $<0.100$ (13 traits).

The highest heritability coefficient had the head profile (0.675). Within the span of 0.300-0.599 were the heritabilities of 4 traits (height at withers, chest girth, chest depth and forehoof width). Three traits showed heritabilities between 0.200-0.299 (croup width and shape, canon bone circumference). The traits with heritabilities $\geq 0.20$ will be suitable as selection criteria, especially those with heritabilities $\geq 0.30$. The 11 traits showed the heritabilities within the interval form 0.100 to 0.299 and the rest of 13 traits had heritabilities below 0.100 .

In Table 7 are the last squares means and standard errors of the linear type trait scores of the grey and black variety and the studs at Kladruby and Slatiňany of National Stud of Kladruby nad Labem on one hand and the private breeders on the other hand. Significant differences between both varieties were found in 13 of 32 traits. These differences result from the distinct development of both varieties after 1918, i.e. the year of the independence declaration of the Czechoslovak Republic when the Austria-Hungary Monarchy ceased. Until 1918 the Old Kladrub horse was bred for ceremonial purposes of the imperial court in Vienna and the clerical hierarchy. These institutions were no more interested in this horses after 1918 and from 1925 to 1940 was the black variety almost extincted. From the beginning of the forties to the half of eighties of the last century an extensive project of the black varietyregeneration started. Since 1945 the black variety was bred in the stud of Slatiňany and the grey variety was kept in the stud of Kladruby. Until this time both varieties were bred separately. From the seventies of the last century the Old Kladrub horses expanded to state and private farms. At this time more than the half of the breed (grey and black horses) is in private hands.

In the year 2005 a new uniform breeding objective for both varieties was formulated with the aim to breed sire lines and dam families in both colours. The linear type classification will be an important source for the realization of this aim. On the other hand this arrangement will be an effective breeding step for conservation of the genetic diversity within the breed. 


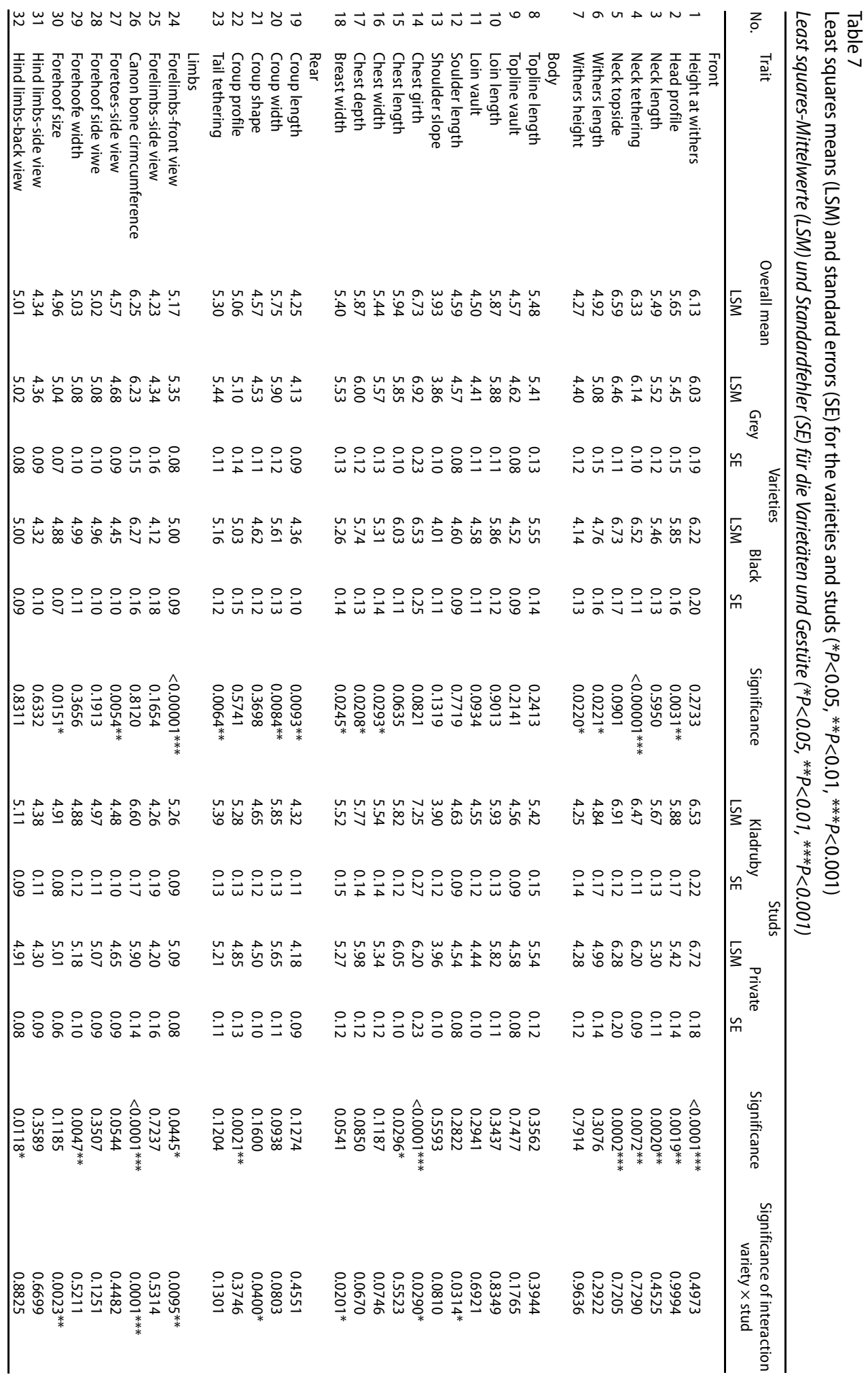



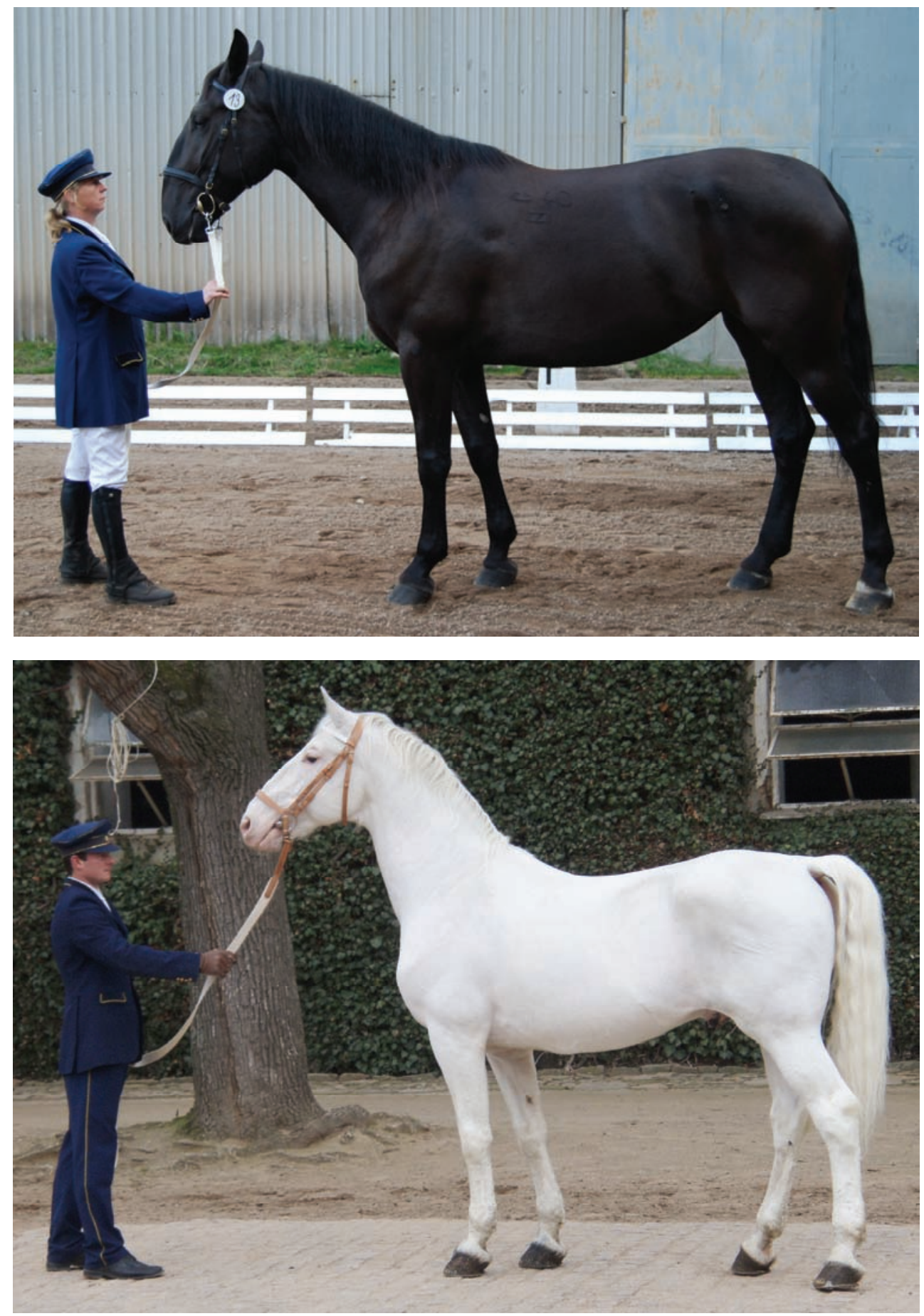

Figure 1

The Old Kladrub horse

Das Altkladruber Pferd 
In the black variety the head profile was more expressed and the neck tethering was higher. Both traits correspond more to the breeding objective. This was due to the consistent selection and the early closing of this population to immigration of genes from other breeds. The withers length and height, chest width, depth and breast width are significantly more expressed in the grey variety.

In the height at withers, neck length and topside and other body traits no significant differences between both varieties were found.

The croup is longer in the black variety. The scores of the croup width, tail tethering, forelimbs front view, foretoes side view and forehoof size are highly significant and significantly higher in the grey variety. No significant differences were found in the croup shape and profile and the rest of the limb traits between both varieties.

Horses of both varieties with the desirable traits will be selected and used for corrective mating to attain the breed uniformity in these linear type traits which show a significant difference in the grey and black variety.

The conformation of the grey variety correspond closer to the breeding goal above all in the wider and deeper chest, larger width of breast and croup, a higher tail tethering, broad forelimbs front view and weaker foretoes (side view). This is due to several factors, as the consequent selection for these traits, immigration of genes from the sire line Favory of the Lippizan breed and the breed Lisutano due to the imported stallion Rudolfo.

The including of private studs in the breeding program is a further important contribution to the conservation of genetic diversity within the breed. Between the Kladruby studs and the private ones highly significant differences were found in five of seven front traits (height at withers, head profile, neck length, tethering and topside), chest girth, croup profile, cannon bone circumference, forehoof width and significant differences between chest length, forelimbs front view and hind limbs back view. The consequence of this fact was a positive response of the horses in the National Stud in the convex head profile, longer neck, convex neck topside, higher chest girth, vault croup profile, broader forelimbs and hind limbs poise. This was also due to the consequent breeding and immigration of favourable genes from breeds of Old Spanish origin (Lipizzan, Lusitano, and Friesian). The horses in the private studs show a higher height at withers, longer chest and broader forehoof. Highly significant and significant interactions variety $\times$ stud were recorded in only 7 traits.

\section{Acknowledgements}

This work was supported by the Ministry of Education, Youth and Sports of the Czech Republic (Project No. MSM 6046070901).

\section{References}

Bowling AT (1994) Population genetics of Great Basin Feral horses. Anim Genet 25 (Suppl 1), 67-74

Dietl G, Hoffmann S, Albrecht S (2004) Parameters and trends of mare inspections of Mecklenburger Warmblut Horse. Arch Tierz 47, 107-17 [in German]

Ekiz B, Kocak Ö, Yilmaz A (2005) Phenotipic and genetic parameter estimates for racing traits of thoroughbted horses in Turkey. Arch Tierz 48, 121-9

Falconer DS, Mackay TFC (1996) Introduction into quantitative genetics. Longman House, Harlow Essex, UK, $464 \mathrm{p}$ 
Fioretti M, Catalano AL, Rosati A, Martuzzi F (2005) Bardigliano horse selection a genetic global index for linear type traits. In: Conservation genetics of endangered horse breeds. EAAP publication 116, 147-54

Kovač M, Groeneveld E, García-Cortes LA (2002) VCE-5 A package for the estimation of dispersion parameters. In: Proc 7th WCGALP CD ROM Commutation No 8-06

Halo M, Mlynek J, Strapák P, Massányi P (2008) Genetic efficiency parameters of Slovak warm-blood horse. Arch Tierz 51, 5-15

Hartman O, Lengerken G, Schwark HJ, Bergfeld U (1994) Linear description of conformation traits in riding horses. EAAP, 5.-8. September 1994, Edinburgh, UK

Hořín P, Cothran EG, Trtková K, Marti E, Glasák V, Henney P, Vyskočil M (1998) Polymorphism of Old Kladruber horses. A surviving but endangered baroque breed. Eur J Immunogenet 25, 357-63

Jakubec V, Jelínek J, Volenec J, Záliš N (1996a) Linear type trait classification system and conformation evaluation of horses Model application - OldKladrub horse. Hipologický věstník Výzkumné centrum chovu koní Slatiňany, Národní hřebčín Kladruby nad Labem, 1, 5-32 [in Czech]

Jakubec V, Glasák V, Jelínek J, Přibyl J, Volenec J, Záliš N (1996b) Genetic analysis of sire lines and sire progeny groups in the Old Kladrub horse. Sci Agricult Bohemica 27, 283-92

Jakubec V, Záliš N, Schlote W, Scholz A, Ondráček M (1998) Linear type trait analysis in the sire lines of the Old Kladrub horse. Sci Agricult Bohemica 29, 17-28

Jakubec V, Schlote W, Jelínek J, Scholz A, Záliš N (1999) Linear type trait analysis in the genetic resource of the Old Kladrub horse. Arch Tierz 44, 215-24

Jakubec V, Záliš N, Jelínek J, Ondráček M, Volenec J (2000) Analysis of the linear type traits and performance characters in the genetic resource »Old Kladrub horse«. Hipologický věstník, Národní hřebčín Kladruby n Labem, 2, 1-44 [in Czech]

Koenen EPC, Van Veldhuizen AE, Brascamp EW Genetic parameters of linear scored conformation traits and their relation with dressage and show-jumping in the Dutch Warmblood Riding Horse population. EAAP, Edinburgh, UK, 5-8 September 1994, 20 p.

Mayrhofer G, Dworak E (1983) About the heterozygosity in cattle and horse. Wien Tierärztl Mschr 70, 27-9 [in German]

Oom MM, Cothrans EG (1994) The genetic variation of an endangered breed the Sorraia horse. In: Proc XXIVth Int Conf on Animal Genetics, July 1994, Prague, CZ

Posta J, Komlósi I, Mihók S (2007) Principal component analysis of preformance test traits in Hungrian sporthorse mares. Arch Tierz 50, 125-35

SAS (1995) SAS User's guide Statistical Analysis System Institute, Inc, Cary, NC, USA

Schlote W, Jakubec V, Schulz A, Umstätter C, Höhne S, Deschan R, Majzlík I, Záliš N, Volenec J (2002) Investigations on standardizing evaluation of external conformation traits using the Old Kladrub Horse as an example. 7th World Congress on Genet Appl to Livest Prod, Montpellier, France

Stübs D, Distl O (2007) Mapping the horse genome and its impact on equine genomics for identification of genes for monogenic and complex traits - a review. Arch Tierz 50, 7-24

Van Bergen HMM, Van Arendonk JAM (1993) Genetic parameters for linear type traits in Shetland ponies Livest Prod Sci 36, 273-84

Volenec J, Jakubec V, Jelínek J, Přibyl J, Záliš N (1995) Analysis of inbreeding of the Old Kladrub horse Sci Agricult Bohemica 16, 279-96

Wright S (1922) Coefficients of inbreeding and relationship. Amer Nat 56, 330-8

Received 3 April 2009, accepted 20 May 2009.

Corresponding author:

Ing. LUBOŠ VOSTRÝ, Ph.D.

email: vostry@af.czu.cz

Czech University of Life Science Prague, Kamýcká 129, 16521 Prague 6-Suchdol, Czech Republic 